\title{
Strategies for cadmium detoxification in the white shrimp Palaemon argentinus from clean and polluted field locations
}

\author{
Leila Chiodi Boudet a, b, *, Julieta Mendieta ${ }^{\text {c, d }}$, María Belén Romero a, b, \\ Arantxa Dolagaratz Carricavur ${ }^{\text {a, b }}$, Paula Polizzi ${ }^{\text {a, b }}$, Jorge E. Marcovecchio ${ }^{\text {e }}$, \\ Marcela Gerpe ${ }^{a, b}$ \\ a Laboratorio de Toxicología Ambiental, Departamento de Ciencias Marinas, Facultad de Ciencias Exactas y Naturales, Universidad Nacional de Mar del \\ Plata, Funes 3350, 7600, Mar del Plata, Argentina \\ ${ }^{\mathrm{b}}$ Instituto de Investigaciones Marinas y Costeras, Consejo Nacional de Investigaciones Científicas y Técnicas (IIMyC-CONICET), Argentina \\ ${ }^{c}$ Instituto de Investigaciones Biológicas, Facultad de Ciencias Exactas y Naturales, Universidad Nacional de Mar del Plata, Funes 3250, 7600, Mar del Plata, \\ Argentina \\ ' Comisión de Investigaciones Científicas de la Provincia de Buenos Aires (CIC), Argentina \\ e Área de Oceanografía Química, Instituto Argentino de Oceanografía (IADO-CONICET/UNS), Bahía Blanca, Argentina
}

\section{H I G H L I G H T S}

- Tolerant and non-tolerant shrimp showed different strategies to detoxify Cd.

- MT synthesis was the main mechanism in Cd detoxification in non-tolerant shrimp.

- The MRG formation was responsible of $\mathrm{Cd}$ resistance in the tolerant population.

\section{A R T I C L E I N F O}

\section{Article history:}

Received 25 April 2019

Received in revised form

24 June 2019

Accepted 25 June 2019

Available online 27 June 2019

Handling Editor: Willie Peijnenburg

Keywords:

Palaemon argentinus

Cadmium

Subchronic exposure

Metallothioneins

Metal rich-granules

\begin{abstract}
A B S T R A C T
In this study, we investigated the metal handling capacity of non-tolerant and tolerant populations of Palaemon argentinus to cadmium (Cd), through evaluating of the main mechanisms of metal detoxification, metallothioneins (MT) and metal-rich granules (MRG), to probe that the presence of MRG in the second population is responsible of that condition. The tolerant population were exposed to 3.06 and $12.26 \mu \mathrm{g} \mathrm{Cd} \cdot \mathrm{L}^{-1}$, while the non-tolerant shrimp were exposed to $3.06 \mu \mathrm{g} \mathrm{Cd} \cdot \mathrm{L}^{-1}$. Each experiment involved the exposure during 3, 7, 10 and 15 days and, the depuration during 7, 14, 21 and 28 days, for which shrimp were transferred to clean water. The range values of MT concentrations for non-tolerant shrimp were: $12.24-23.91 \mu \mathrm{gg}$ (w.w), while for tolerant shrimp were: $8.75-16.85 \mu \mathrm{gg}$ (w.w); MRG levels were: $0.12-0.57 \mu \mathrm{gg}$ (w.w) and $0.3-2.1 \mu \mathrm{gg}$ (w.w), respectively. The results showed different strategies for Cd detoxification: the induction of MT was the main pathway in the non-tolerant population, while the formation of Cd-MRG was the main mechanism for tolerant shrimp. These differences could be related to the environmental history and the health status of each populations.
\end{abstract}

(c) 2019 Elsevier Ltd. All rights reserved.

\section{Introduction}

Cadmium (Cd) is a nonessential toxic metal, water-soluble that has a high capacity to bioaccumulate in aquatic invertebrates. Cadmium forms stable complexes with proteins (Bridges et al.,

\footnotetext{
* Corresponding author. Laboratorio de Toxicología Ambiental, Departamento de Ciencias Marinas, Instituto de Investigaciones Marinas y Costeras, Universidad Nacional de Mar del Plata, Funes 3350, Mar del Plata, 7600, Argentina.

E-mail address: leilachiodi@mdp.edu.ar (L. Chiodi Boudet).
}

2006), by displacement of the essential metals at structural and catalytic positions, resulting in loss of function, and subsequently cytotoxicity due to the disruption of cell signaling and $\mathrm{Ca}^{2+}-$ homeostasis (Janssens et al., 2009). Cadmium is known to be genotoxic (Pavlaki et al., 2016), and it has been demonstrated to inhibit the repair of DNA and to cause lipid peroxidation (Bertin and Averbeck, 2006).

Aquatic invertebrates possess diverse strategies in the handling and storage of metals that allow them to cope with elevated concentrations in the environment (Rainbow, 2002, 2007). Once 
assimilated, metals usually go through a series of metabolic processes and are subsequently incorporated into various cellular components (Bednarska et al., 2017; Wang and Rainbow, 2005). For aquatic invertebrates, trace elements are potentially stored in two different detoxified forms: metallothioneins (MT) and various types of metal-rich granules (MRG) (Goto and Wallace, 2007; Bednarska et al., 2017). Metallotioneins, a family of low molecular weight (6-7 kDa), cysteine-rich metal-binding proteins have been shown to occur in most zoological taxa (Binz and Kägi, 1999). It is generally thought that these proteins play a primary role in the homeostasis of essential metals such as zinc ( $\mathrm{Zn})$ and copper ( $\mathrm{Cu}$ ), as well as being involved in the detoxification of nonessential metals, such as Cd (Viarengo et al., 2000). They have been widely used as biomarkers of metal exposure in aquatic organisms, as their synthesis is induced as a result of exposure to metal contaminants (Romero-Isart and Vašák, 2002). Additionally, there is increasing evidence that MTs may also have an antioxidant role, acting as scavengers of free radicals and reactive oxygen species (Cavaletto et al., 2002; Correia et al., 2002a; Viarengo et al., 2000).

Numerous metals, among them $\mathrm{Cd}, \mathrm{Cu}$, and $\mathrm{Zn}$, can also be sequestered as electrondense granules, the occurrence, form, and function of which have been the subject of several reviews (Ahearn et al., 2004; Marigomez et al., 2002; Rainbow, 2007; Vivjer et al., 2004). Like MT, MRGs serve as biomarkers of trace-element toxicity (Correia et al., 2002b), and they are present in most macro-invertebrate phyla (Ahearn et al., 2004; Corrêa et al., 2002; Khan et al., 2010). They occur intra- or extracellularly and are associated with organs that have digestive, storage or excretory functions (Nassiri et al., 2000). In some cases, the relative enhancement of one of these fractions can reflect preferential storage in one particular detoxified form (MT or MRG), with increasing metal contamination (Mouneyrac et al., 2002). Therefore, they may be used to assess the metal handling capacities of aquatic organisms chronically exposed to trace metals and to elucidate the mechanisms involved in population - or speciesspecific tolerance to trace elements (Goto and Wallace, 2009).

Palaemon (= Palaemonetes) argentinus (Crustacea: Decapoda: Caridea) is a freshwater shrimp of ecologic interest because of its abundance in the north and centre of Argentina, in Uruguay, and in southern Brazil (Morrone and Lopreto, 1995). Due to its abundance, it plays a very important role in trophic chains, sustaining a great variety of fish and birds (Azevedo et al., 2004). Being a detritivorous species, it plays a key role in the nutrient cycle and consequently in the energy balance in their habitats (Reinsel et al., 2001). Several authors reported their sensitivity to toxicants both in laboratory tests (Bertrand et al., 2015, 2016; Chiodi Boudet et al., 2015; Collins and Capello, 2006; Lavarías and García, 2015) and in the field through active monitoring (Bertrand et al., 2018). Therefore, this species can be used as a bioindicator to provide information on environmental quality (Montagna and Collins, 2007). In a previous study, $P$. argentinus from contaminated sites were more tolerant to $\mathrm{Cd}$ than shrimp from uncontaminated areas. In addition, shortterm exposure $(96 \mathrm{~h}$ ) of non-tolerant shrimp showed a fast induction of MT synthesis while tolerant shrimp did not induce MT nor oxidative stress (Chiodi Boudet et al., 2013). This contrasting pattern between populations allows to hypothesize the presence of MRG in the tolerant population as the main mechanism to cope $\mathrm{Cd}$ concentrations. Therefore, the goal of this study was to evaluate the mechanisms and strategies involved in Cd detoxification in both tolerant and non-tolerant shrimp during subchronic and depuration assays. The depuration assay allows to evaluate their capacity of recovery after the restitution of the water quality, with the elimination of the stressor.

\section{Materials and methods}

\subsection{Specimens}

Freshwater shrimp, Palaemon argentinus, were collected with a hand net and immediately transferred to the laboratory. They were obtained from Los Padres lagoon ( $37^{\circ} 57^{\prime}$ S, $57^{\circ} 44^{\prime} \mathrm{W}$ ) and Nahuel Ruca lagoon $\left(37^{\circ} 37^{\prime} \mathrm{S}-57^{\circ} 25^{\prime} \mathrm{W}\right)$, both located in one of the most productive agricultural area of Buenos Aires Province, Argentina. Los Padres lagoon (LP) is surrounded by horticultural fields and their sediments have high metal concentrations $\left(0.7 \mu \mathrm{g} \mathrm{Cd} \cdot \mathrm{g}^{-1}\right.$; $1 \mu \mathrm{g} \mathrm{Hg} \cdot \mathrm{g}^{-1} ; 72 \mu \mathrm{g} \mathrm{Cr} \cdot \mathrm{g}^{-1} ; 15.3 \mu \mathrm{g}$ As $\cdot \mathrm{g}^{-1}, 119 \mu \mathrm{g} \mathrm{Zn} \cdot \mathrm{g}^{-1}$; Chiodi Boudet et al., 2008), that exceed the levels safe for the biota (CCME, 2002). Nahuel Ruca lagoon (NR) is located within a reserve (Program for Man and Biosphere, MAB, UNESCO) (Martínez, 2001) and their sediments has low metal concentrations and are below the limit established as safe for biota (Chiodi Boudet et al., 2010). Previous studies demonstrated that shrimp from LP lagoon have a higher tolerance to $\mathrm{Cd}$ relative to those from NR lagoon, evidenced by $\mathrm{LC}_{50}-96 \mathrm{~h}$ values, reflecting the environmental history (Chiodi Boudet et al., 2013).

Organisms were acclimated for three days in $140 \mathrm{~L}$ glass aquaria filled with aerated freshwater $(\mathrm{pH}=8.30 \pm 0.05$, water hardness $=235 \mathrm{mg} \mathrm{CaCO}_{3} \cdot \mathrm{L}^{-1}$ ), maintained at constant laboratory temperature $\left(17.0 \pm 0.9{ }^{\circ} \mathrm{C}\right)$ and under a 12h: $12 \mathrm{~h}$ light: dark photoperiod. During acclimation, those aquaria that had more than $2 \%$ mortality were not used for the experiments (Khan et al., 1988). All along this period, they were fed daily ad libitum with commercial food for fish (Tetramin, Germany).

\subsection{Subchronic exposure and depuration assay}

Two days before the onset of each experiment, adult shrimps (body length $>2.2 \mathrm{~cm}$; Donatti, 1986) of $P$. argentinus were randomly distributed in sixteen 20 -L glass aquaria filled with aerated freshwater. The density was five individuals per liter along all the experiment (100 individuals per aquaria). The Cd concentrations were selected according to previous studies and $\mathrm{LC}_{50}-96 \mathrm{~h}$ values for $\mathrm{Cd}$ of each shrimp population $\left(\mathrm{LC}_{50}: 24.50\right.$ and $12.26 \mu \mathrm{g}$ $\mathrm{Cd} \cdot \mathrm{L}^{-1}$ for $\mathrm{LP}$ and NR population, respectively) (Chiodi Boudet et al., 2013). The tolerant population (LP) were exposed to 3.06 and $12.26 \mu \mathrm{g} \mathrm{Cd} \cdot \mathrm{L}^{-1}$, while the non-tolerant $(\mathrm{NR})$ were only exposed to $3.06 \mu \mathrm{g} \mathrm{Cd} \cdot \mathrm{L}^{-1}$, because $12.26 \mu \mathrm{g} \mathrm{Cd} \cdot \mathrm{L}^{-1}$ is lethal for $50 \%$ of exposed population at $96 \mathrm{~h}$.

Each experiment involved the exposure during 3, 7, 10 and 15 days and, the depuration during 7, 14, 21 and 28 days, for which shrimp exposed for 15 days were transferred to clean water. Each exposure and depuration condition had its corresponding control. All along the experiments, shrimp were fed before the renewal of the medium (every $48 \mathrm{~h}-50 \%$ of total volume); retiring uneaten food immediately. All other conditions were kept the same as those used for acclimation. The shrimp were checked daily and dead individuals were removed and counted, being the absence of response to gentle mechanical stimulus the criterion for death.

At the end of each treatment, shrimp were cryoanesthetized and hepatopancreas were dissected carefully. The hepatopancreas is the main organ involved in the accumulation and detoxification of metals (Núñez Nogueira et al., 2006) and was, therefore, the object of interest for this study. Finally, samples were frozen with liquid nitrogen and kept at $-80^{\circ} \mathrm{C}$ until analysis.

\subsection{Reagents and metal analysis}

All reagents were of analytical grade supplied by Sigma-Aldrich 
and Merck (Germany). Double distilled water $\left(\mathrm{ddH}_{2} \mathrm{O}\right)$ was used to prepare standard solutions, dilutions, and blanks. All glassware and aquaria used were left with nitric acid solution overnight and then washed with $\mathrm{ddH}_{2} \mathrm{O}$ to avoid metal contamination. A stock metal solution was prepared using $\mathrm{CdCl}_{2}$ (99.9\%) and specific aliquots were taken to provide nominal metal concentrations.

Water samples from exposure aquaria were taken before starting metal exposure to check the nominal concentrations. Samples were acidified to $2 \%$ with $\mathrm{HNO}_{3}$ and measured by Anodic Stripping Voltammetry (ASV) following the technique described by Andrade et al. (2006).

\subsection{Metallothionein assay}

MT concentrations were measured in pooled samples of hepatopancreas (5-6 individuals $\approx$ approx. weight $30 \mu \mathrm{g}$ ) according to the methodology described by Viarengo et al. (1997). Application of this methodology yields a partially purified metalloprotein fraction by acidic ethanol/chloroform fractionation of the tissue homogenate. During extract preparation, MT is denatured by low $\mathrm{pH}$ and high ionic strength. MT concentration in extracts is measured by spectrophotometry employing the Ellman's - $\mathrm{SH}$ reagent (5, 5dithio-bis 2-nitrobenzoic acid; DTNB). According to Viarengo et al. (1997), procedures performed during sample preparation allow obtaining a complete MT precipitation and avoid oxidation of -SH groups, contamination by soluble low molecular weight thiols, and enzymatic protein degradation. Three measurements were performed for each treatment. The amount of MT was calculated as was described by Chiodi Boudet et al. (2013). The MT concentration was reported as $\mu \mathrm{g}$ of MT per gram of wet tissue.

\subsection{Cd in metal rich granules (Cd-MRG)}

The Cd in metal rich granules (Cd-MRG) in hepatopancreas tissue ( $\approx$ approx. weight $150 \mu \mathrm{g}$ ) were obtained by differential centrifugation following the method of Wallace et al. (2003). The MRG fraction was digested with perchloric and nitric acid (1:3) according to the FAO/SIDA method (1983) to determine Cd bound to this subcellular fraction. The $\mathrm{Cd}$ concentration was measured with ICP-OES by triplicate. Analytical accuracy was determined using blanks and certified reference material of the National Research Council of Canada (LUTS-1, Lobster hepatopancreas). The values obtained in the reference material for $\mathrm{Cd}$ were between 24.37 and $26.7 \mathrm{mg} \mathrm{Cd} \cdot \mathrm{kg}^{-1}(24.9 \pm 1.0)$, that they were within the confidence range of certified value $\left(26.7 \pm 0.6 \mathrm{mg} \mathrm{Cd} \cdot \mathrm{kg}^{-1}\right)$. The CdMRG concentration was reported as $\mu \mathrm{g}$ of $\mathrm{Cd}$ per gram of wet tissue.

\subsection{SDS-PAGE and western blot analysis}

The spectrometric determination is an analytical procedure based on several characteristics of MT, but it does not guarantee that the target molecule is a true MT. Therefore, SDS-PAGE and Western blot (WB) techniques were used to confirm the presence of MT in shrimp samples and estimate their molecular weight. The supernatants (containing MT) obtained from the MT assay were used. Protein concentration was determined by the bicinchoninic acid (Sigma Aldrich) method (Hill and Straka, 1988). The SDS-PAGE, which was performed according to Laemmli's procedure (Laemmli, 1970 ), consisted of $4.5 \%$ acrylamide stacking gel and a $12 \%$ resolving gel containing $0.1 \%$ SDS and $0.75 \mathrm{~mm}$ thick. Samples were heated at $100{ }^{\circ} \mathrm{C}$ for $4 \mathrm{~min}$ in SDS-mercaptoethanol loading buffer to minimize negative charge differences and disulfide linkages. Each sample $(40 \mu \mathrm{l})$ was divided in half, and each $20 \mu \mathrm{l}$ was applied (60 $\mu \mathrm{g}$ per lane) to gel. After electrophoresis, one gel was stained with Coomassie Brilliant Blue R-250. The molecular weights were estimated by comparison of electrophoresis mobility with those of the standard marker proteins (ranging from 12000-225000 Da, Amersham Full-Range Rainbow Molecular Weight, GE Healthcare). A commercially pure standard of MT (apoMT 1A/2B rabbit mixture, Bestenbalt, Estonia) was used as positive control. In addition, the SDS-PAGE gel was electroblotted by semidry protein transfer to a nitrocellulose membrane (Novex ${ }^{\circledR}$, Semi-Dry Blotter, Invitrogen). The nitrocellulose membrane was blocked for $12 \mathrm{~h}$ with $5 \%$ dried milk in TRIS-buffered saline solution $\mathrm{pH} 7.5$ containing $0.1 \%(\mathrm{v} / \mathrm{v})$ Tween-20 (TBST). Then, it was incubated for $1 \mathrm{~h}$ with a 1:500 dilution of anti-MT polyclonal rabbit antibody, washed with TBST solution, and incubated for $2 \mathrm{~h}$ with 1:10000 dilution of anti-rabbit antibody conjugated with alkaline phosphatase (Sigma-Aldrich, USA). The blotted protein was revealed using 5-bromo-4-chloro-3indolyl phosphate/nitroblue tetrazolium solution.

\subsection{Statistical analysis}

The data were checked for variance homogeneity by Levene's test and for distribution normality by Shapiro-Wilk's test. Significant differences were assessed by parametric tests: $t$-test and oneway analysis of variance (ANOVA) followed by the post-hoc Tukey test if the conditions were met, or with non-parametric tests: UMann-Whitney and Kruskall-Wallis with post-hoc Dunn test (Zar, 2010). The significance level was $\mathrm{p}<0.05$. All statistical analyses were performed using STATISTICA version 8.0 (Statsoft, Inc.).

\section{Results}

The analytical concentrations of Cd in water samples were between $95 \%$ and $99 \%$ of the nominal value. The measured concentration (mean \pm standard deviation) for $12.26 \mu \mathrm{g} \mathrm{Cd} \cdot \mathrm{L}^{-1}$ was $11.98 \pm 0.22 \mu \mathrm{g} \mathrm{Cd} \cdot \mathrm{L}^{-1}$; while the analytical determination for $3.06 \mu \mathrm{g} \mathrm{Cd} \cdot \mathrm{L}^{-1}$ was not possible due to the limit of detection of the technique $\left(5 \mu \mathrm{g} \mathrm{Cd} \cdot \mathrm{L}^{-1}\right)$. The survival of NR (non-tolerant) and LP (tolerant) shrimp exposed to $3.06 \mu \mathrm{g} \mathrm{Cd} \cdot \mathrm{L}^{-1}$, varied from 98 to $100 \%$ along exposure and depuration, as well as for controls. In the case of tolerant shrimp exposed to $12.26 \mu \mathrm{g} \mathrm{Cd} \cdot \mathrm{L}^{-1}$, the survival began to decrease from 10d (92\%), declining to $87 \%$ at $15 \mathrm{~d}$. During depuration assays, the survival values varied from 85 to $89 \%$.

\subsection{SDS-PAGE and WB analysis}

The SDS-PAGE assay showed several bands, one of which had a relative molecular weight similar to the pure MT standard used as positive control ( $25 \mathrm{kDa}$ vs $24 \mathrm{kDa}$, respectively) (Fig. 1A). To confirm this, a WB analysis was performed with anti-MT antibody. As expected, the antibody reacted with MT standard band showing that the band of $25 \mathrm{kDa}$ was revealed by anti-MT antibody (Fig. 1B).

\subsection{MT concentrations}

The exposure of NR shrimp to $3.06 \mu \mathrm{g} \mathrm{Cd} \cdot \mathrm{L}^{-1}$ produced a significant increase in MT levels for all exposure times ( $t$-test, $p<0.05$ ) with respect to their controls (Fig. $2 \mathrm{~A}$ ). In addition, it was observed a significant increase along exposure, reaching the maximum level at 10d (ANOVA with post-hoc Tukey test, $p<0.05$ ). The concentrations in control shrimp did not show differences among them. In the first week of depuration, the MT levels decreased significantly (ANOVA with post-hoc Tukey test, $p<0.05$ ) with respect to those observed in the exposure assay. During the following weeks, levels remained with no significant changes (ANOVA, $p>0.05$ ). The concentrations in control shrimps did not show differences during depuration period except those for $7 d$, which were significantly lower than 14d and 21d (ANOVA, post-hoc Tukey test, $p<0.05$ ). 

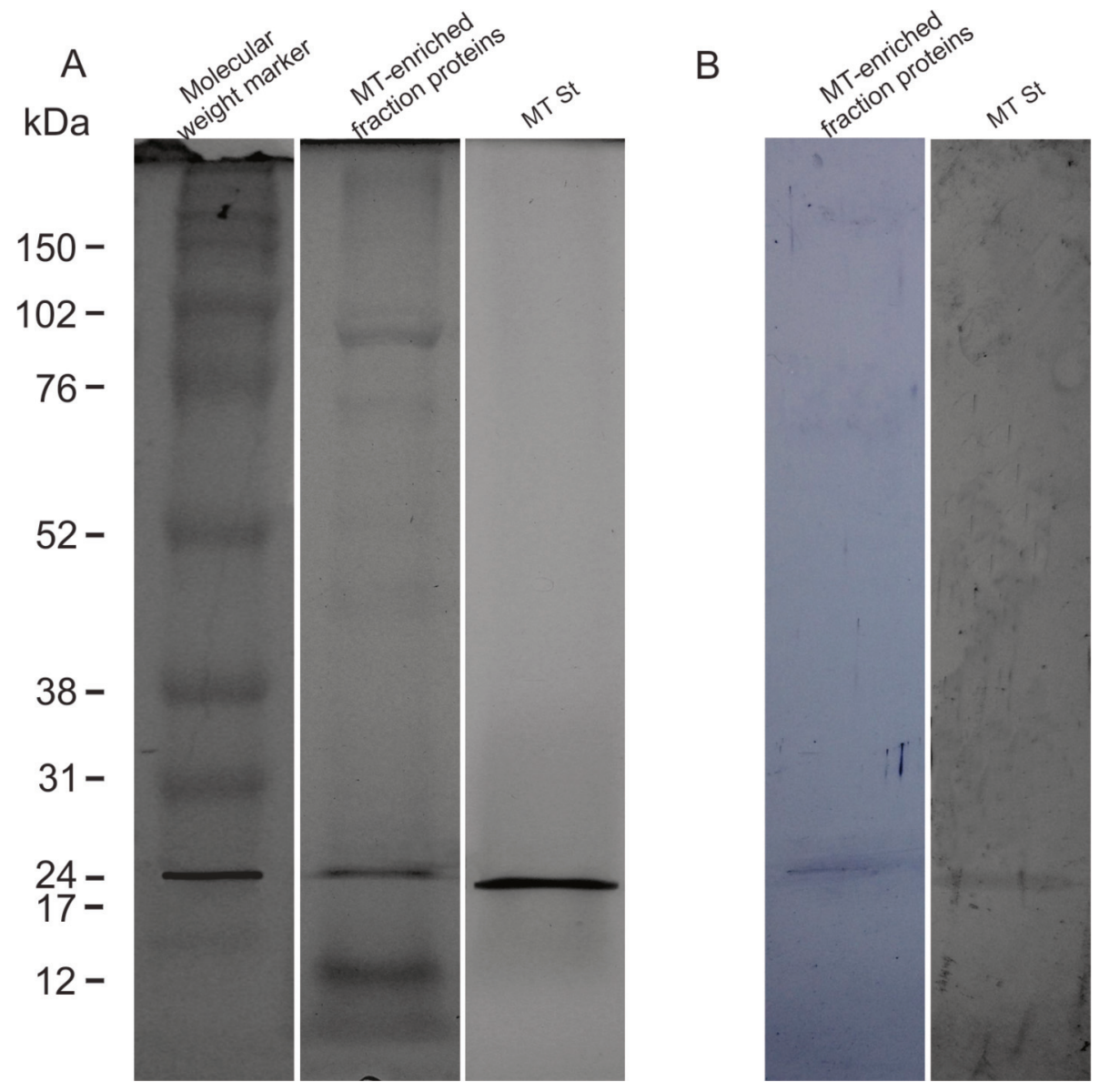

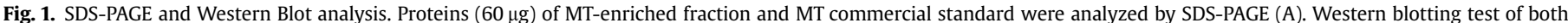
samples were performed and bands were revealed with anti-MT polyclonal antibody (B).

In contrast, the exposure of LP shrimp to $3.06 \mu \mathrm{gCd} \cdot \mathrm{L}^{-1} \mathrm{did}$ not cause an increase in MT levels (Fig. 2 B), with no significant differences both respect to their control and among the different exposure times. In addition, controls did not show significant differences among them, except those for 10d, which were higher than the rest (ANOVA with post-hoc Tukey test, $p<0.05$ ). During depuration no significant variations in MT levels were observed (ANOVA, $p>0.05$ ), either with the control or among days.

In the experiment of $12.26 \mu \mathrm{gCd} \cdot \mathrm{L}^{-1}$, during the first week ( 3 and 7d), MT levels remained unchanged (Fig. 2 C). In contrast, for 10 and $15 \mathrm{~d}$, an increase was observed with respect to their controls $(t-$ test, $\mathrm{p}<0.05$ ) as well as with $3 \mathrm{~d}$ of exposure (ANOVA with post-hoc Tukey test, $p<0.05$ ). During the first two weeks of depuration, the MT levels were unchanged with respect to 10 and $15 \mathrm{~d}$ of exposure. In addition, concentrations at 7 and 14d were significantly higher than those for 21 and 28d (ANOVA, post-hoc Tukey test, $p<0.05$ ). MT levels in controls were unchanged along depuration period, except those for $7 d$, which were significantly higher than $14 d$ (ANOVA, post-hoc Tukey test, $p<0.05$ ).

\subsection{Cd in metal rich granules}

The exposure of NR shrimp to $3.06 \mu \mathrm{g} \mathrm{Cd} \cdot \mathrm{L}^{-1}$ produced a significant increase of Cd-MRG concentrations with respect to their controls ( $t$-test and U-Mann Whitney test, $p<0.05$ ) for all times (Fig. $3 \mathrm{~A}$ ). In addition, a gradual increase with the exposure time was observed, reaching the maximum concentrations at $15 \mathrm{~d}$ (ANOVA with post-hoc Tukey test, $p<0.05$ ). In the first week of depuration (7d), it was observed a sharp decrease respect to the $15 \mathrm{~d}$ of exposure ( $t$-test, $p<0.05$ ), remaining unchanged during the rest of the assay. However, the concentrations for all remained significantly higher than their controls ( $t$-test and U-Mann Whitney test, $p<0.05)$. Unfortunately, it was not possible to analyze the depuration at 28d due to lack of samples. The Cd-MRG levels in controls did not show differences during the exposure and depuration period.

The exposure of LP shrimp to $3.06 \mu \mathrm{g} \mathrm{Cd} \cdot \mathrm{L}^{-1}$ produced a significant increase of Cd-MRG concentrations with respect to their controls ( $t$-test and U-Mann Whitney test, $p<0.05$ ) for all times (Fig. $3 \mathrm{~B}$ ). The concentrations reached the maximum value at $15 \mathrm{~d}$ (ANOVA with post-hoc Tukey test, $p<0.05$ ). Similarly to NR shrimp, during the first week of depuration there was a significant decrease of Cd-MRG concentrations respect to $15 \mathrm{~d}$ of exposure ( $t$-test, $p<0.05$ ), remaining unchanged during the rest of the assay. At all depuration times, the concentrations were significantly higher than their controls ( $t$-test and U-Mann Whitney test, $p<0.05$ ). It should be mentioned that the concentrations in the LP shrimp doubled, and even tripled in some cases, relative to those observed in the NR shrimp (both exposed to 3.06) for all exposure and purification times.

For LP shrimp exposed to $12.26 \mu \mathrm{g} \mathrm{Cd} \cdot \mathrm{L}^{-1}$, there was a significant increase of Cd-MRG concentrations for all times with respect to their controls (U-Mann Whitney test, p <0.05) (Fig. $3 \mathrm{C}$ ). The concentrations reached the maximum value at $15 \mathrm{~d}$, which were significantly higher than those of 3 and 7d (ANOVA with post-hoc Tukey test, $p<0.05)$. In similar way, during the first week of 

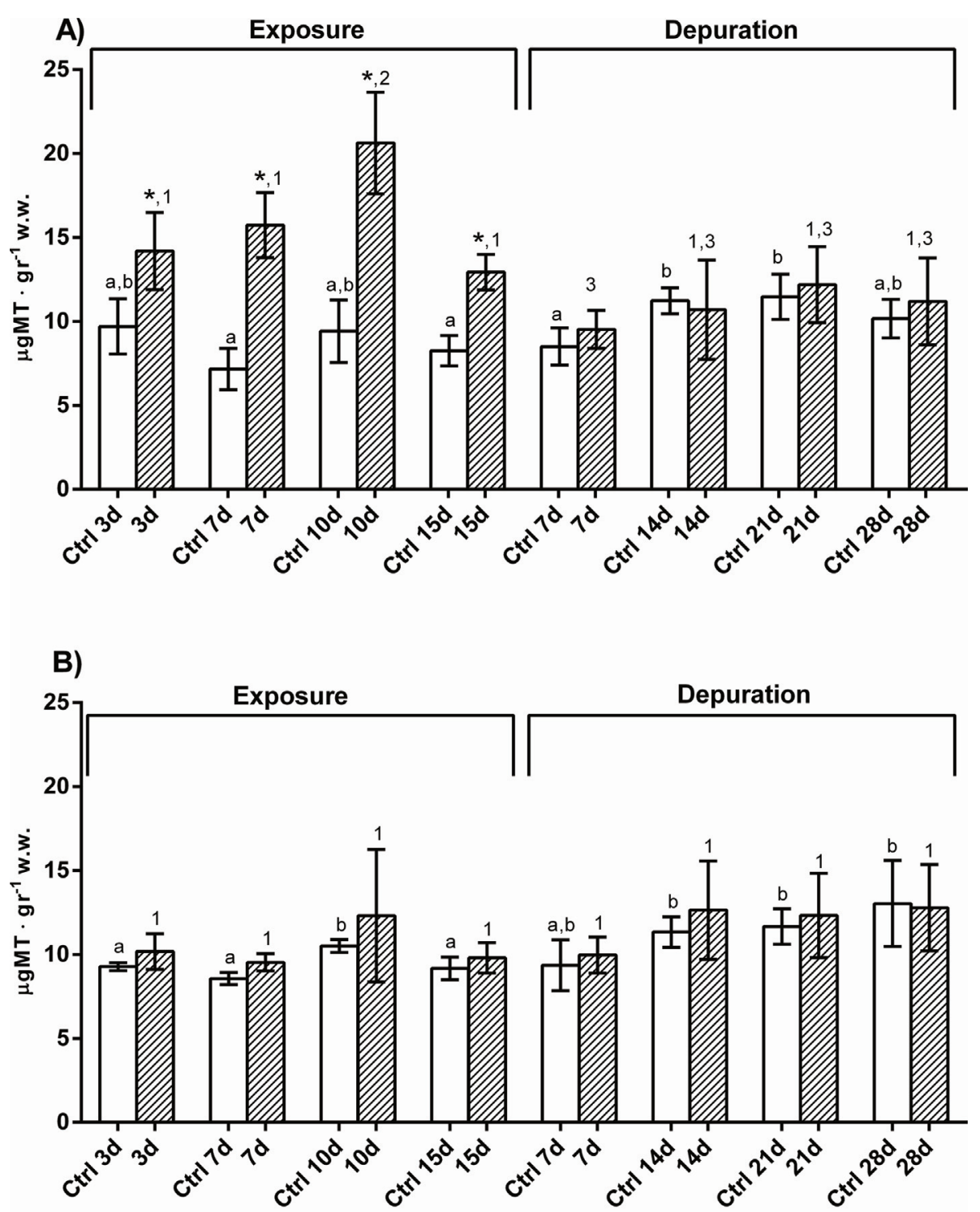

C)

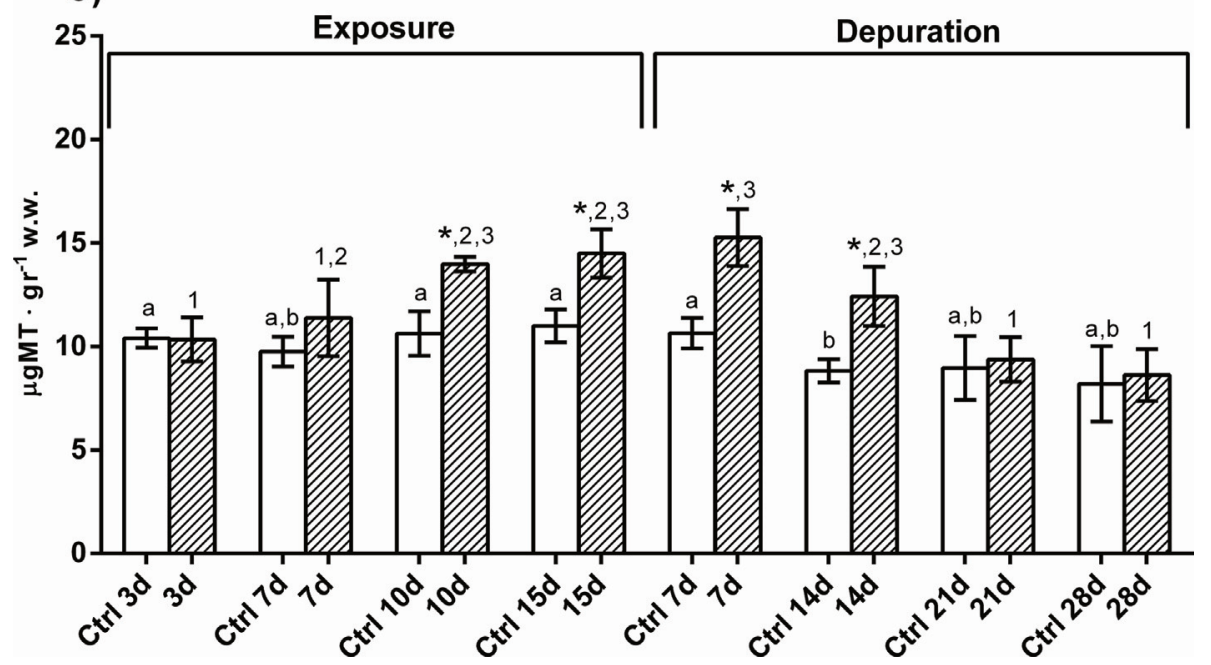

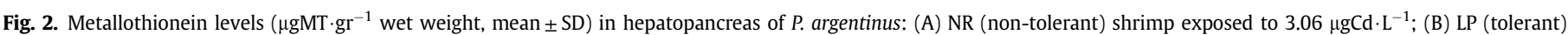

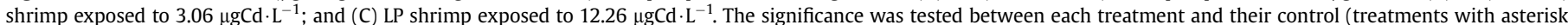

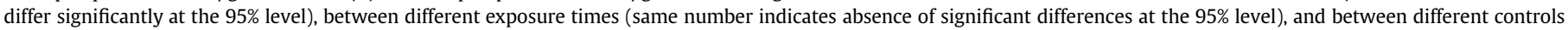
(same letter indicates absence of significant differences at the $95 \%$ level). 


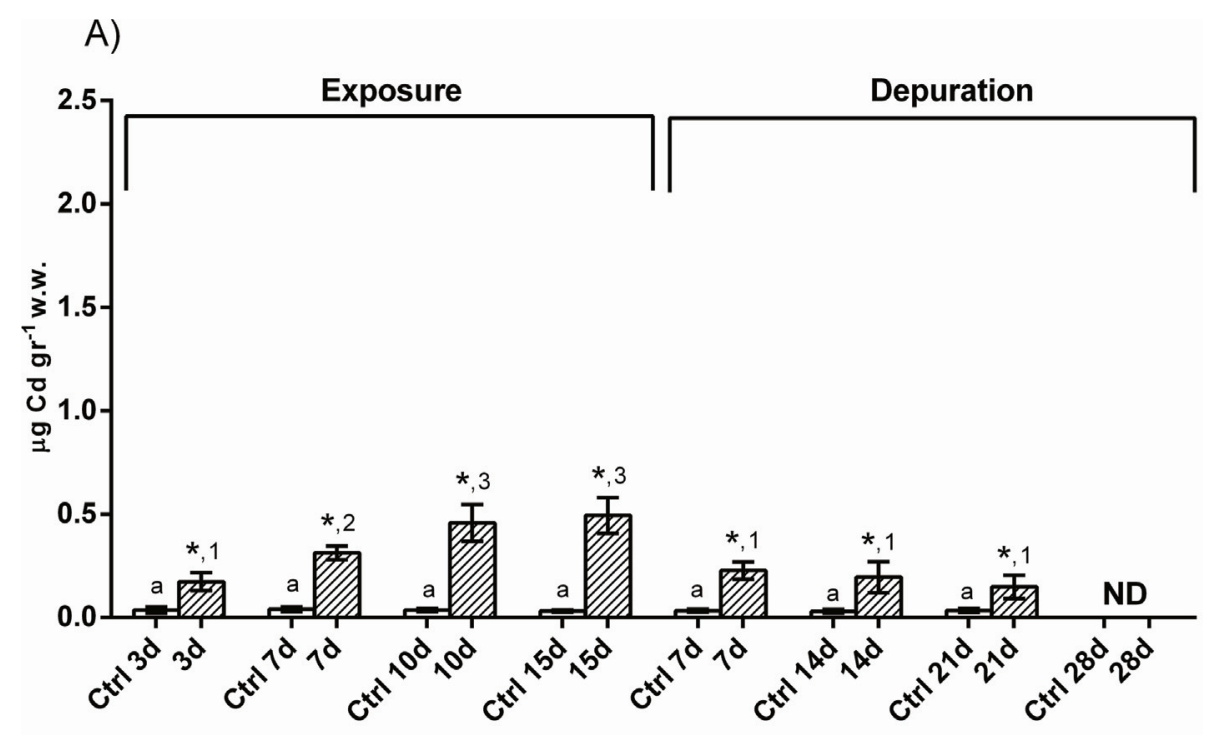

B)

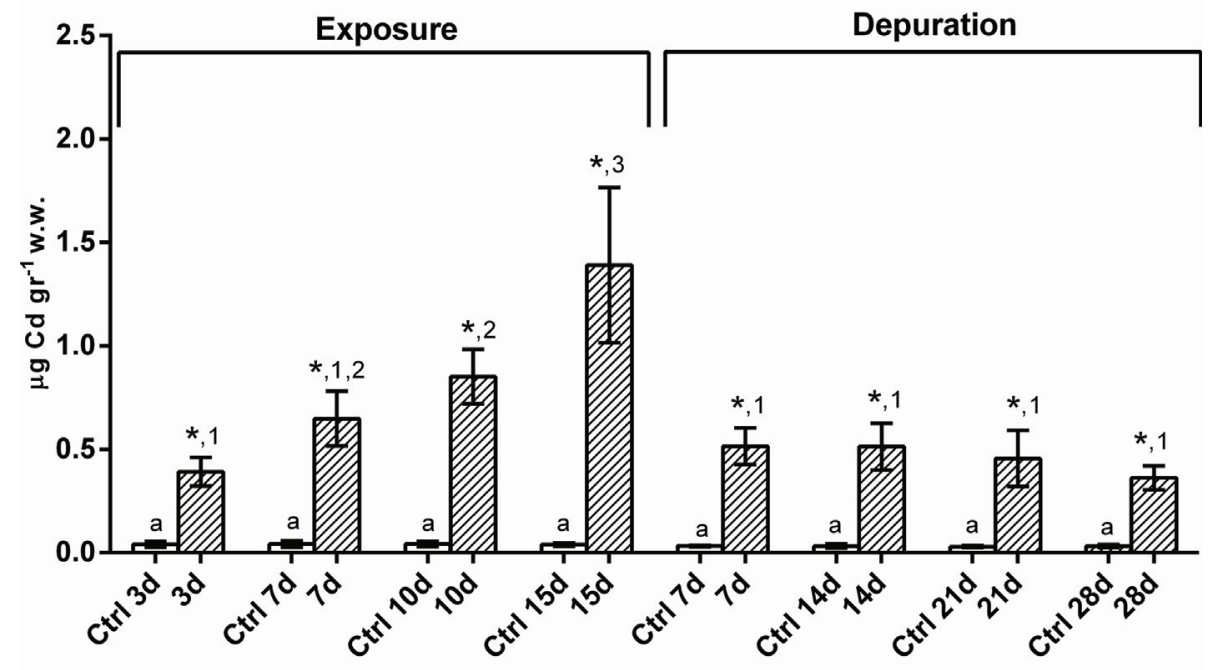

C)

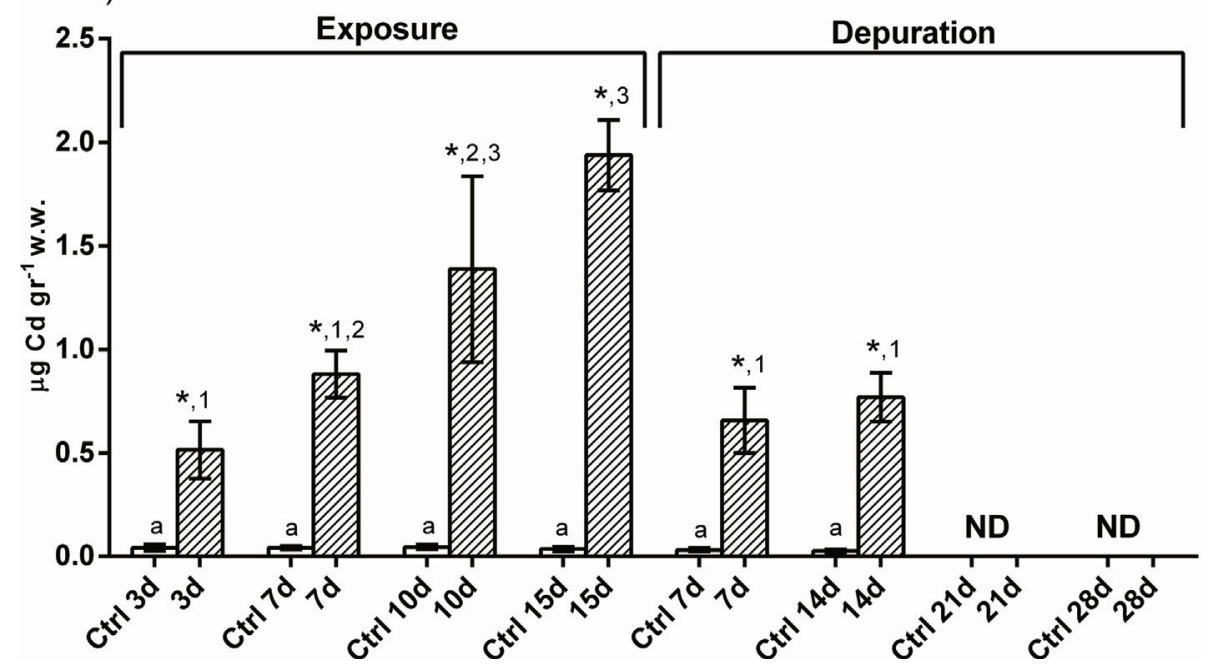

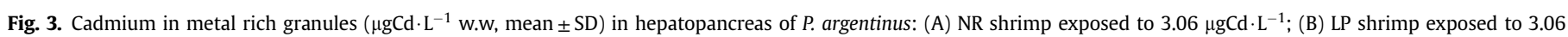

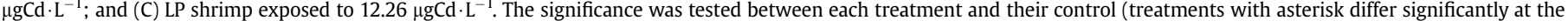

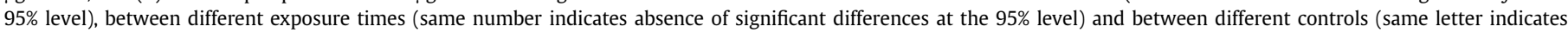
absence of significant differences at the 95\% level). ND: not determined. 
depuration there was a sharp decrease of Cd-MRG concentrations respect to $15 \mathrm{~d}$ of exposure ( $t$-test, $p<0.05$ ), without differences between 7 and 14d concentrations. Unfortunately, it was not possible to determine Cd-MRG at 21 and $28 \mathrm{~d}$ of depuration due to lack of samples. The Cd-MRG levels in controls did not show differences during the exposure and depuration period.

\section{Discussion}

\subsection{Occurrence of MTs in shrimp hepatopancreas}

Recent studies have reported the presence of MT in P. argentinus by spectrophotometric analysis (Chiodi Boudet et al., 2013) and differential pulse polarography (Bertrand et al., 2015, 2016). However, a biochemical analysis by SDS-PAGE and WB had not been performed until this study. These techniques identified the MT protein using a proper primary and secondary antibody; demonstrating the occurrence of $24 \mathrm{kDa}$ MT in shrimp hepatopancreas. The molecular weight of this putative MT coincides with the average mass of MTs found in several aquatic invertebrate species. Mackay et al. (1993) reported two different groups of MTs in the mussel Mytilus edulis having apparent molecular weight of 10 and $20 \mathrm{kDa}$, respectively. MTs with molecular weight ranging from 7 to $25 \mathrm{kDa}$ were found in heavy metal-exposed marine mussel (Viarengo et al., 1997). On the other hand, studies performed in the polychaete Eurythoe complanata, exposed to different metals, revealed MTs of molecular weights between 10 and $20 \mathrm{kDa}$, as well as, heavier MTs (>60 kDa) (Marcano et al., 1996). In the American oyster Crassostrea virginica exposed to $\mathrm{Cd}$ and $\mathrm{Cu}$, two MT-like proteins with molecular weights of $10 \mathrm{kDa}$ and $24 \mathrm{kDa}$ were detected (Engel, 1999). Likewise, SDS-PAGE assays conducted with the amphipod Gammanus locusta revealed a putative MT of $23 \mathrm{kDa}$ inducible by $\mathrm{Cu}$ exposure (Correia et al., 2004). These discrepancies related to the molecular weight $(6-7 \mathrm{kD})$ can be explained by the unusual properties of MT; their multiple sulfhydryl groups lead to the formation of multimeric complexes, and therefore overestimate its molecular weight (Correia et al., 2004; Costa et al., 2008).

\subsection{Strategies of cadmium detoxification}

The development of strategies to avoid metal induced toxicity often occurs out of necessity through exposure to elevated concentrations (Khan et al., 2011). Consequently, prior natural exposure may confer a degree of tolerance that is absent in populations from uncontaminated areas. Tolerant crustaceans generally possess physiological or biochemical mechanisms that allow them to cope with elevated levels of bioavailable metals in the environment (Mason and Jenkins, 1995; Vigneron et al., 2015). These mechanisms include sequestration by MTs (Mason and Jenkins, 1995; Roesijadi, 1992) and formation of MRG (Klerks and Bartholomew, 1991; Mason and Jenkins, 1995). The current study indicated that both mechanisms were present in $P$. argentinus, although there were variations between tolerant and non-tolerant populations.

The MT induction was the main detoxification pathway of $\mathrm{Cd}$ for the non-tolerant population (NR). Its synthesis was induced from $3 \mathrm{~d}$ of exposure, suggesting that the physiological response to $\mathrm{Cd}$ contamination was fast. Similar results have been reported in other studies (Barka et al., 2001; Bodar et al., 1988; Del Ramo et al., 1995; Martinez et al., 1996; Viarengo et al., 1985), which indicates that Cd is a potent inducer of MT synthesis (Klaassen, 2001). The maximum capacity of induction was occurred at $10 \mathrm{~d}$ of exposure, which involved levels up to $23.91 \mu \mathrm{gMT} \cdot \mathrm{g}^{-1}$ w.w., two-fold higher than control levels. In the copepod Tigriopus brevicornis, the maximum capacity occurred with the $24 \mathrm{~h}$ of exposure with levels close to 1.6 $\mu \mathrm{gMT} \cdot \mathrm{g}^{-1}$ w.w., which were 5-fold higher than the controls (Barka et al., 2001). Also, the brachiopod Artemia parthenogenetica and the amphipod Echinogammarus echinosetosus reached their maximum induction capacity at $24 \mathrm{~h}$ of exposure, with values up to 110 and 9 $\mu \mathrm{gMT} \cdot \mathrm{g}^{-1}$ w.w. (Martinez et al., 1996), respectively. On the other hand, the decapod Litopenaeus vannamei reached its maximum capacity of induction at 56 days of exposure with levels close to 250 $\mu \mathrm{gMT} \cdot \mathrm{g}^{-1}$ w.w. (Wu and Chen, 2005). In all these cases, organisms came from uncontaminated environments. Therefore, it appears that MT response to $\mathrm{Cd}$ exposure is very variable among crustaceans. This variability can be due to numerous factors specific to each species, such as size, sex, and stage of moult (Amiard et al., 2006), which does not allow a direct comparison. However, characterization of the MT response (time and capacity) provides insight into the interspecific differences of vulnerability to $\mathrm{Cd}$ contamination. In general, a high capacity of MT induction is related to a lower vulnerability to metal contamination (Del Ramo et al., 1995; Martinez et al., 1993; Nordberg and Nordberg, 2009). In the case of $P$. argentinus, the observed levels of MT induction, among the lowest reported for crustaceans, could explain the high sensitivity to Cd for the species (Chiodi Boudet et al., 2013). The decrease in MT levels at 15d of exposure could be a manifestation of the toxic effect of $\mathrm{Cd}$. This idea is supported by the findings of $\mathrm{Wu}$ and Chen (2005), which showed that MT induction in the shrimp L. vannamei was limited after long-term exposure. In the amphipod, Orchestia gammarellus, the absence of MT induction or even a depletion of MT concentrations were observed at high Cd doses (Mouneyrac et al., 2002). It is generally agreed that Cd can cause a decrease in MT levels due to an impact on the normal structure and functioning of hepatopancreas, causing physiological and metabolic changes (Wu and Chen, 2005). A previous study of $P$. argentinus demonstrated an increase of lipid peroxidation (LPO) levels at $15 \mathrm{~d}$ of exposure and histological alterations in the hepatopancreatic tissue (Chiodi Boudet et al., 2015), indicating the toxic effects of Cd. Lipid peroxidation (LPO), is one of the main biomarkers of oxidative damage, and it has been reported as a major contributor to the loss of cellular function (Hermes-Lima et al., 1995). The decrease in MT levels continued during depuration until eventually returning to the initial levels, probably due to the elimination of the stressor. Moksnes et al. (1995) observed a similar pattern in L. vannamei, attributing the loss of MT to the decrease in internal Cd concentrations, which would be related to the decrease of available $\mathrm{Cd}$.

The formation of $\mathrm{Cd}$ granules was also present in the nontolerant population, although their levels were very low in comparison to those observed in the tolerant population. Similar results were reported in the oligochaetes Hediste diversicolor and Limnodrilus hoffmeisteri, where non-resistant worms from unpolluted sites sequestered the majority of Cd into MT (Berthet et al., 2003 and Wallace et al., 1998, respectively). Some authors postulated that the formation of metal granules is a mechanism for long-term storage, while the MT is involved in time scales shorter (Brown, 1982; Roesijadi, 1992).

The tolerant population (LP), also presented the two mechanisms (MT and MRG), although the MRG formation was the main detoxification pathway of $\mathrm{Cd}$. This is consistent with earlier studies in invertebrates from metal-polluted habitats, depositing large amounts of metals in the form of granules. For instance, the oligochaete L. hoffmeisteiri (Wallace et al., 1998) and polychaetes H. diversicolor and Neanthes japonica (Berthet et al., 2003; Fan et al., 2015) preferred to sequester Cd into MRG; the amphipods Corophium volutator and $O$. gammarellus from copper-contaminated sites formed $\mathrm{Cu}$ insoluble granules in cells of the hepatopancreas (Icely and Nott, 1980; Nassiri et al., 2000). Many authors (Bodar et al., 1990; Corrêa et al., 2002; Leland and Kuwabara, 1985) 
consider the presence of MRG as a physiological adaptation to the accumulation of toxic metals. Apparently, the sequestration into MRG may be more efficient in detoxifying Cd than MTs (Goto and Wallace, 2009; Wallace et al., 1998), allowing organisms living in polluted habitats to tolerate higher levels of $\mathrm{Cd}$.

As mentioned above, there was no MT induction at lower concentration $\left(3.06 \mu \mathrm{gCd} \cdot \mathrm{L}^{-1}\right)$ at any time, while at highest concentration $\left(12.26 \mu \mathrm{gCd} \cdot \mathrm{L}^{-1}\right)$ there was a slight MT induction at the end of the exposure. In this case, the lack of induction would not seem to be related to a toxic effect of $\mathrm{Cd}$, taking into account that the nontolerant population exposed to $3.06 \mu \mathrm{gCd} \cdot \mathrm{L}^{-1}$ induces its synthesis, doubling the MT levels. The maintenance of a tolerance mechanism may be energetically expensive (Postma et al., 1995; Voets et al., 2009). Increased metal resistance is often associated with a trade-offs in energetic cost and fitness (Campbell et al., 2005; Kwok et al., 2009). For instance, Xie and Klerks (2004) demonstrated that the killifish Heterandria formosa with a Cd resistance through multigeneration exposure, exhibited a significantly lower fecundity and produced smaller sized offspring than the control populations. A similar situation could be occurring in the tolerant population of $P$. argentinus, in which it has been reported a low level of fitness indicated by small adult size, low percentage of ovigerous females during the breeding season, fewer eggs, high loss of eggs and low fertility (Ituarte, 2008). On the other hand, organisms in good condition, as reported by Chiodi Boudet et al. (2015) for NR shrimp (non-tolerant population), might be able to invest more energy in metal detoxification (Voets et al., 2009). Protein synthesis is energetically costly (Hawkins, 1991), while MRG formation would have little or no cost (Simkiss, 1991, 1996: Davies and Simkiss, 1996). This could explain the differences observed between tolerant and nontolerant shrimp with respect to MT synthesis. Given the physical condition of the tolerant population, the Cd-MRG formation is more advantageous than MT synthesis.

The different strategies adopted by each population could have trophic consequences due to the Cd transfer, and potentially cause secondary toxic effects in their predators (Baines et al., 2002; Ni et al., 2000). As trace metals bound to MT are readily solubilized by the digestive processes of a predator, metals associated with these proteins are thought to be more available to a predator than those with MRG (Wallace et al., 2003; Zhang and Wang, 2006; Goto and Wallace, 2009), although these consequences must be tested in $P$. argentinus in future evaluations.

The depuration period allowed reaching initial MT values in those groups where its induction was observed. In the case of CdMRG, the purification period was not sufficient to reach the initial values, which was confirm only for the tolerant population exposed to $3.06 \mu \mathrm{gCd} \cdot \mathrm{L}^{-1}$. As already mentioned, some depuration times could not be analyzed for the other two assays due to the lack of sample. Both populations showed a decrease in MRG levels during the first week of depuration, which implies that the granules were eliminated. The highest amount of MRG is generally found in senescent R-cells in the proximal region of the hepatopancreas tubules (Corrêa et al., 2002; Vogt and Quinitio, 1994; Vogt, 2015). These cells do not exhibit apocrine secretion, therefore contaminants must remain inside the cells until cellular death (Vogt and Quinitio, 1994). Some authors have reported that granules are eliminated during the epithelial renovation at the end of each digestive cycle, and then are excreted through the faeces (Hopkin and Nott, 1979; Vogt and Quinitio, 1994). In this process, senescent cells and the mineral concretions are released while the new epithelium is constructed below (Brown, 1982). On the other hand, part of the epithelium of hepatopancreas is renewed in each molting cycle (Hopkin, 1989), and the granules could be also eliminated. In this context, it is noteworthy that during the first days of depuration it was observed a large number of molts during assays for both populations, although it was only an observation. This event coincided with the decrease in Cd-MRG levels. The granules pattern observed in $P$. argentinus during depuration appeared to be related to the moult, with a sharp decrease during the first week which stabilized during the remainder of depuration.

\section{Conclusions}

Our results revealed that both MT and MRG play important roles in the storage and detoxification of $\mathrm{Cd}$ in P. argentinus. They were differences in $\mathrm{Cd}$ detoxification between non-tolerant and $\mathrm{Cd}$ tolerant shrimp populations indicating different strategies of metal handling. The formation of Cd-MRG was the main mechanism for detoxification in the tolerant population, indicating its fundamental role in the tolerance of this population. In contrast, MT induction was the main detoxification pathway of $\mathrm{Cd}$ in the non-tolerant population. These differences could be related to their environmental history and the health status of the studied shrimp populations. Our results show the variable sensitivity of this species and provide insight for the interpretation of results from both in laboratory and in field studies.

\section{Acknowledgements}

This work was partially supported by grants from CONICET (PIP 0348/2010) and Mar del Plata University (EXA780/16). Authors are very grateful to Mr. Pedro Urrutia and Mr. Jorge Lucero for the assistance during sampling. Ph.D. R. Davis (Texas A\&M University, USA) to English revision.

\section{References}

Ahearn, G., Mandal, P., Mandal, A., 2004. Mechanisms of heavy-metal sequestration and detoxification in crustaceans: a review. J. Comp. Physiol. B 174, 439-452.

Amiard, J., Amiard-Triquet, C., Barka, S., Pellerin, J., Rainbow, P., 2006. Metallothioneins in aquatic invertebrates: their role in metal detoxification and their use as biomarkers. Aquat. Toxicol. 76, 160-202.

Andrade, S., Moffett, J., Correa, J., 2006. Distribution of dissolved species and suspended particulate copper in an intertidal ecosystem affected by copper mine tailings in Northern Chile. Mar. Chem. 101, 203-212.

Azevedo, C., Castro, E., Tomassoni, D., Morini, M., Querol, E., 2004. Aspectos da biologia e ecologia de Palaemonetes argentinus (Nobili, 1901) (Crustacea Decapoda, Palaemonidae) na arroio Felizardo, bacia do médio Rio Uruguai, Uruguaiana, Rio Grande do Sul, Brasil. Biotemas 17, 91-106.

Baines, S.B., Fisher, N.S., Stewart, R., 2002. Assimilation and retention of selenium and other trace elements from crustacean food by juvenile striped bass (Morone saxatilis). Limnol. Oceanogr. 46, 646-655.

Barka, S., Pavillon, J., Amiard, J., 2001. Influence of different essential and nonessential metals on MTLP levels in the copepod Tigriopus brevicornis. Comp. Biochem. Physiol., C 128, 479-493.

Bednarska, A., Świątek, Z., Paciorek, K., Kubińska, N., 2017. Effect of cadmium bioavailability in food on its compartmentalisation in carabids. Ecotoxicology 26, 1259-1270.

Berthet, B., Mouneyrac, C., Amiard, J., Amiard-Triquet, C., Berthelot, Y., Le Hen, A Mastain, O., Rainbow, P., Smith, B., 2003. Accumulation and soluble binding of cadmium, copper, and zinc in the polychaete Hediste diversicolor from coastal sites with different trace metal bioavailabilities. Arch. Environ. Contam. Toxicol. $45,468-478$

Bertin, G., Averbeck, D., 2006. Cadmium: cellular effects, modifications of biomolecules, modulation of DNA repair and genotoxic consequences (a review). Biochimie 88, 1549-1559.

Bertrand, L., Monferrán, M., Métais, I., Mouneyrac, C., Amé, M., 2015. MTs in Palaemonetes argentinus as potential biomarkers of zinc contamination in freshwaters. Ecol. Indicat. 48, 533-541.

Bertrand, L., Monferrán, Mouneyrac, C., Bonansea, R., Asis, R., Amé, M., 2016. Sensitive biomarker responses of the shrimp Palaemonetes argentinus exposed to chlorpyrifos at environmental concentrations: roles of alpha-tocopherol and metallothioneins. Aquat. Toxicol. 179, 72-81.

Bertrand, L., Monferrán, M., Mouneyrac, C., Amé, M., 2018. Native crustacean species as a bioindicator of freshwater ecosystem pollution: a multivariate and integrative study of multi-biomarker response in active river monitoring. Chemosphere 206, 265-277.

Binz, P., Kägi, J., 1999. Metallothionein: molecular evolution and classification. In: Klaassen, C. (Ed.), Metallothionein IV. Birkhäuser Verlag, Basel, pp. 7-13. 
Bodar, C., Kluytmans, Van Montfort, J., Vogt, P., Zandee, D., 1988. Cadmium resistance and the synthesis of metallothionein-like proteins in Daphnia magna. In: Proceedings of the Third International Conference of Environmental Contamination. CEP, Edinburg, pp. 79-81.

Bodar, C., van der Sluis, I., Van Montfort, J., Vogt, P., Zandee, D., 1990. Cadmium resistance in Daphnia magna. Aquat. Toxicol. 16, 33-40.

Bridges, J., Benford, D., Hubbard, S., 2006. Mechanism of toxic injury. Ann. N. Y. Acad. Sci. 407, 42-63.

Brown, B., 1982. The form and function of metal-containing "granules" in invertebrate tissues. Biol. Rev. 57, 621-667.

Campbell, P., Giguere, A., Bonneris, E., Hare, L., 2005. Cadmium-handling strategies in two chronically exposed indigenous freshwater organisms - the yellow perch (Perca flavescens) and the floater mollusc (Pyganodon grandis). Aquat. Toxicol. 72, 83-97.

Cavaletto, M., Ghezzi, A., Burlando, B., Evangelisti, V., Cerratto, N., Viarengo, A., 2002 Effect of hydrogen peroxide on antioxidant enzymes and metallothionein leve in the digestive gland of Mytilus galloprovincialis. Comp. Biochem. Physiol., C 131, 447-455.

CCME, 2002. Canadian Sediment Quality Guidelines for the Protection of Aquatic Life. Canadian Council of Ministers of the Environment. http://www.ccme.ca/ publications/ceqg_rcqe.html?category_id=124. (Accessed 14 May 2017).

Chiodi Boudet, L., Plá, R., Moreno, M., Invernizzi, R., Moreno, V., Gerpe, M., 2008 Impacto por metales pesados en la Laguna de los Padres, Provincia de Buenos Aires, Argentina. In: En: Avances en Toxicología y Química Ambiental. SETAC $2^{\text {nd }}$ Meeting in Argentina.

Chiodi Boudet, L., Escalante, A., von Haeften, G., Moreno, V., Gerpe, M., 2010. Assessment of heavy metal accumulation in two aquatic macrophytes: a field study. J. Braz. Soc. Ecotoxicol. 5, 1-13.

Chiodi Boudet, L., Polizzi, P., Romero, M.B., Robles, A., Gerpe, M., 2013. Lethal and sublethal effects of cadmium in the white shrimp Palaemonetes argentinus: comparison between populations from contaminated and reference sites. Ecotoxicol. Environ. Saf. 89, 52-58.

Chiodi Boudet, L.,P., Polizzi, M., Romero, Robles, A., Marcovecchio, J., Gerpe, M., 2015. Histopathological and biochemical evidence of hepatopancreatic toxicity caused by cadmium in white shrimp, Palaemonetes argentinus. Ecotoxicol. Environ. Saf. 113, 231-240.

Collins, P., Capello, S., 2006. Cypermethrin toxicity to aquatic life: bioassays for the freshwater prawn Palaemonetes argentinus. Arch. Environ. Contam. Toxicol. 51, 79-85.

Corrêa, J., Farina, M., Allodi, S., 2002. Cytoarchitectural features of Ucides cordatus (Crustacea, Decapoda) hepatopáncreas: structure and elemental composition of electron-dense granules. Tissue Cell 34, 315-325.

Correia, A., Livingstone, D., Costa, M., 2002a. Effects of water-borne copper on metallothionein and lipid peroxidation in the marine amphipod Gammarus locusta. Mar. Environ. Res. 54, 357-360.

Correia, A., Costa, M., Ryan, K., Nott, J., 2002b. Studies on biomarkers of copper exposure and toxicity in the marine amphipod Gammarus locusta (Crustacea): 1 Copper-containing granules within the midgut gland. J. Mar. Biol. Assoc. U. K. $82,827-834$

Correia, A., Sousa, A., Costa, M., Moura, I., Livingstone, D., 2004. Quantification of metallothionein in whole body Gammarus locusta (Crustacea: Amphipoda) using differential pulse polarography. Toxicol. Environ. Chem. 86, 23-36.

Costa, P., Repolho, T., Caeiro, S., Diniz, M., Moura, I., Costa, M., 2004. Modelling metallothionein induction in the liver of Sparus aurata exposed to metal contaminated sediments. Ecotoxicol. Environ. Saf. 71, 117-124.

Davies, N., Simkiss, K., 1996. Biominerals as trace elements sinks. In: Allemand, D. Cuif, J.-P. (Eds.), Biomineralization in Environmental Studies and Aquaculture, Vol. 4. Bulletin de l'Institut océanographique, Musée océanographique, Monaco, no spécial, vol. 14, pp. 209-214.

Del Ramo, J., Torreblanca, A., Martinez, M., Pastor, A., Diaz-Mayans, J., 1995. Quantification of cadmium-induced metallothionein in crustaceans by the silversaturation method. Mar. Environ. Res. 39, 121-125.

Donatti, O., 1986. Algunos aspectos biecológicos del camarón Palaemonetes argen tinus (Nobili, 1901) en el embalse San Roque, Córdoba (Argentina). Rev Hydrobiol. Trop. 19, 45-60.

Engel, D., 1999. Accumulation and cytosolic partitioning of metals in the American oyster Crassostrea virginica. Mar. Environ. Res. 47, 89-102.

Fan, W., Xu, Z., Wang, W.-X., 2015. Contrasting metal detoxification in polychaetes, bivalves and fish from a contaminated bay. Aquat. Toxicol. 159, 62-68.

Food and Agriculture Organization/Styrelsen För Internationellt Utverklingssamarbete (FAO/SIDA), 1983. Manual de métodos de investigación del medio ambiente acuático. In: Parte 9. Análisis de presencia de metales y organoclorados en los peces, vol. 212. FAO Documento Técnico de Pesca, pp. 1-35.

Goto, D., Wallace, W., 2007. Interaction of Cd and $\mathrm{Zn}$ during uptake and loss in the polychaete Capitella capitata: whole body and subcellular perspectives. J. Exp. Mar. Biol. Ecol. 352, 65-77.

Goto, D., Wallace, W., 2009. Relevance of intracellular partitioning of metals in prey to differential metal bioaccumulation among populations of mummichogs (Fundulus heteroclitus). Mar. Environ. Res. 68, 257-267.

Hawkins, A., 1991. Protein turnover: a functional appraisal. Funct. Ecol. 5, 222-233.

Hermes-Lima, M., Willmore, W., Storey, K., 1995. Quantification of lipid peroxidation in tissue extracts based on Fe (III) xylenol orange complex formation. Free Radical Biol. Med. 643, 271-280.

Hill, H., Straka, J., 1988. Protein determination using bicinchoninic acid in the presence of sulfhydryl reagents. Anal. Biochem. 170, 203-208.
Hopkin, S., 1989. Ecophysiology of Metals in Terrestrial Invertebrates. Elsevier Applied Science, Barking, UK, p. 366.

Hopkin, S., Nott, J., 1979. Some observations on concentrically structured, intracellular granules in the hepatopancreas of the shore crab Carcinus maenas (L.). J. Mar. Biol. Assoc. U. K. 59, 867-877.

Icely, J., Nott, J., 1980. Accumulation of copper within the "hepatopancreatic" caeca of Corophium volutator (Crustacea: Amphipoda). Mar. Biol. 57, 193-199.

Ituarte, R., 2008. Efectos de la salinidad sobre la reproducción y el desarrollo del "camarón de agua dulce" Palaemonetes argentinus. Tesis doctoral. Universidad Nacional de Mar del Plata, p. 196.

Janssens, T., Roelofs, D., van Straalen, N., 2009. Molecular mechanisms of heavy metal tolerance and evolution in invertebrates. Insect Sci. 16, 3-18.

Khan, A., Weis, J., D'andrea, L., 1988. Studies of cadmium tolerance in two populations of grass shrimp, Palaemonetes pugio. Bull. Environ. Contam. Toxicol. 40, 30-34.

Khan, F., Bury, N., Hogstrand, C., 2010. Cadmium bound to metal rich granules and exoskeleton from Gammarus pulex causes increased gut lipid peroxidation in zebrafish following single dietary exposure. Aquat. Toxicol. 96, 124-129.

Khan, F., Irving, J., Bury, N., Hogstrand, C., 2011. Differential tolerance of two Gammarus pulex populations transplanted from different metallogenic regions to a polymetal gradient. Aquat. Toxicol. 102, 95-103.

Klaassen, C. (Ed.), 2001. Casarett and Doull's Toxicology: the Basic Science of Poisons. Mc Graw Hill Professional, New York, p. 1236pp.

Klerks, P., Bartholomew, P., 1991. Cadmium accumulation and detoxification in a Cdresistant population of the oligochaete Limnodrilus hoffmeisteri. Aquat. Toxicol. 19, 97-112.

Kwok, K., Grist, E., Leung, K., 2009. Acclimation effect and fitness cost of copper resistance in the marine copepod Tigriopus japonicus. Ecotoxicol. Environ. Saf. $72,358-364$.

Laemmli, U., 1970. Cleavage of structural proteins during the assembly of the head of bacteriophage T4. Nature 227, 680-685.

Lavarías, S., García, C., 2015. Acute toxicity of organophosphate fenitrothion on biomarkers in prawn Palaemonetes argentinus (Crustacea: Palaemonidae). Environ. Monit. Assess. 187, 65.

Leland, H., Kuwabara, J., 1985. Trace metals. In: Rand, G.M., Petrocelli, S.R. (Eds.), Fundamentals of Aquatic Toxicology. Hemisphere, New York, pp. 374-415.

Mackay, E., Overnell, J., Dunbar, B., Davidson, I., Hunziker, P., Kägi, J., Fothergill, J., 1993. Complete amino acid sequences of five dimeric and four monomeric forms of metallothionein from the edible mussel Mytilus edulis. Eur. J. Biochem. 218, 183-194.

Marcano, L., Nusetti, O., Rodríguez-Grau, J., Vilas, J., 1996. Uptake and depuration of copper and zinc in relation to metal-binding protein in the polychaete Eurythoe complanata. Comp. Biochem. Physiol. 114, 179-184.

Marigomez, I., Soto, M., Carajaville, M., Angulo, E., Giamberini, L., 2002. Cellular and subcellular distribution of metals in molluscs. Microsc. Res. Tech. 56, 358-392.

Martínez, M., 2001. Avifauna de Mar Chiquita. Pp. 227-250. In: Iribarne, O. (Ed.), Reserva de Biosfera Mar Chiquita: características físicas, biológicas y ecológicas. Editorial Martín, Mar del Plata.

Martinez, M., Torreblanca, A., Del Ramo, J., Pastor, A., Diaz-Mayans, J., 1993. Cadmium induced metallothionein in hepatopancreas of Procambarus clarkii: quantification by a silver-saturation method. Comp. Biochem. Physiol. 10 (2), 263-261.

Martinez, M., Del Ramo, J., Torreblanca, A., Diaz-Mayans, J., 1996. Cadmium toxicity, accumulation and metallothionein induction in Echinogammarus echinosetosus. J. Environ. Sci. Health A 31 (7), 1605-1617.

Mason, A., Jenkins, K., 1995. Metal detoxification in aquatic organisms. In: Tessier, A., Turner, D. (Eds.), Metal Speciation and Bioavailability in Aquatic Systems. John Wiley \& Sons, Chichester, pp. 479-609.

Moksnes, P.-O., Lindahl, U., Haux, C. 1995. Metallothionein as a bioindicator of heavy metal exposure in the tropical shrimp, Penaeus vannamei: a study of dose-dependent induction. Mar. Environ. Res. 39, 143-146.

Montagna, M., Collins, P., 2007. Survival and growth of Palaemonetes argentinus (Decapoda; Caridea) exposed to insecticides with chlorpyrifos and endosulfan as active element. Arch. Environ. Contam. Toxicol. 53, 371-378.

Morrone, J.J., Lopreto, E.C., 1995. Parsimony analysis of endemicity of freshwater Decapoda (Crustacea: Malacostraca) from southern South America. Neotropica $41,3-8$

Mouneyrac, C., Amiard, J., Amiard-Triquet, C., Cottier, A., Rainbow, P., Smith, B., 2002. Partitioning of accumulated trace metals in the talitrid amphipod crustacean Orchestia gammarellus: a cautionary tale on the use of metallothionein-like proteins as biomarkers. Aquat. Toxicol. 57, 225-242.

Nassiri, Y., Rainbow, P., Amiard-Triquet, C., Rainglet, F., Smith, B., 2000. Trace-metal detoxification in the ventral caeca of Orchestia gammarellus (Crustacea: Amphipoda). Mar. Biol. 136, 477-484.

Ni, I.H., Wang, W.X., Tam, Y.K., 2000. The transfer of Cd, Cr and Zn from zooplankton prey to mudskipper (Periophthalmus cantonensis) and glassy (Ambassis urotaenia) fishes. Mar. Ecol. Prog. Ser. 194, 203-211.

Nordberg, M., Nordberg, G., 2009. Metallothioneins: historical development and overview. In: Sigel, A., Sigel, H., Sigel, R. (Eds.), Metallothioneins and Related Chelators. Met. Ions Life Sci, vol. 5, pp. 1-29.

Núñez Nogueira, G., Smith, B., Rainbow, P., 2006. Assimilation efficiency of zinc and cadmium in the decapod crustacean Penaeus indicus. J. Exp. Mar. Biol. Ecol. 332, 75-83.

Pavlaki, M., Araujo, M., Cardoso, D., Silva, A., Cruz, A., Mendo, S., Soares, A., Calado, R., Loureiro, S., 2016. Ecotoxicity and genotoxicity of cadmium in 
different marine trophic levels. Environ. Pollut. 215, 203-212.

Postma, J., Mol, S., Larsen, H., Admiraal, W., 1995. Life cycle changes and zinc shortage in cadmium tolerant midges, Chironomus riparius (Diptera) reared in the absence of cadmium. Environ. Toxicol. Chem. 14, 117-122.

Rainbow, P., 2002. Trace metal concentrations in aquatic invertebrates: why and so what? Environ. Pollut. 120, 497-507.

Rainbow, P., 2007. Trace metal bioaccumulation: Models, metabolic availability and toxicity. Environ. Int. 33, 576-582.

Reinsel, K. Glas, P. Rayburn, J., Pritchard, M., Fisher, W., 2001. Effects of food availability on survival, growth, and reproduction of the grass shrimp Palaemonetes pugio: a laboratory study. Mar. Ecol. Prog. Ser. 220, 231-239.

Roesijadi, 1992. Metallothioneins in metal regulation and toxicity in aquatic animals. Aquat. Toxicol. 22, 81-114.

Romero-Isart, N., Vašák, M., 2002. Advances in the structure and chemistry of metallothioneins. J. Inorg. Biochem. 88, 388-396.

Simkiss, K., 1991. Amorphous minerals and theories of biomineralization. In: Suga, S., Nakahara, H. (Eds.), Mechanisms and Phylogeny of Mineralization in Biological Systems. Springer, Tokyo, pp. 375-381.

Simkiss, K., 1996. Amorphous minerals in biology. In: Allemand, D., Cuif, J.-P. (Eds.), Fundamentals of Biomineralization, Vol. 1. Bulletin de l'Institut océanographique, Musée océanographique, Monaco, no spécial, vol. 14, pp. 49-54.

Viarengo, A., Burlando, B., Ceratto, N., Panfoli, I., 2000. Antioxidant role of metallothioneins: a comparative overview. Cell Mol. Biol. 46, 407-417.

Viarengo, A., Moore, M.N., Pertica, M., Mancinelli, G., Zanicchi, G., Pipe, R., 1985. Detoxification of copper in the cells of the digestive gland of mussels: the role of lysosomes and thioneins. Sci. Total Environ. 44, 135-145.

Viarengo, A., Ponzano, E., Dondero, F., Fabbari, R., 1997. A simple spectrophotometric method for metallothionein evaluation in marine organisms: an aplication to mediterranean and antarctic molluscs. Mar. Environ. Res. 44, 69-84.

Vigneron, A., Geffard, O., Coquery, M., François, A., A., Quéau, H., Chaumot, A., 2015. Evolution of cadmium tolerance and associated costs in a Gammarus fossarum population inhabiting a low-level contaminated stream. Ecotoxicology 24,
$1239-1249$

Vivjer, M., Vangestel, C., Lanno, R., Vanstraalen, N., Peijnenburg, W., 2004. Interna metal sequestration and its ecotoxicological relevance: a review. Environ. Sci. Technol. 38, 4705-4712.

Voets, J., Redeker, E., Blust, R., Bervoets, L., 2009. Differences in metal sequestration between zebra mussels from clean and polluted field locations. Aquat. Toxicol 93, 53-60.

Vogt, G., 2015. Cell biology research on steam cells, aging, cancer resistance, and epigenetics in marbled crayfish and relatives: potential benefits for human biology and medicine. In: Kawai, T., Faulkes, Z., Scholtz, G. (Eds.), Freshwater Crayfish: A Global Overview. CRC Press, Boca Ratón, Florida, pp. 115-160.

Vogt, G., Quinitio, E., 1994. Accumulation and excretion of metal granules in the prawn, Penaeus monodon, exposed to water-borne copper, lead, iron and calcium. Aquat. Toxicol. 28, 223-241.

Wallace, W., Lee, B., Luoma, S., 2003. Subcellular compartmentalization of Cd and Zn in two bivalves. I. Significance of metal-sensitive fractions (MSF) and biologically detoxified metal (BDM). Mar. Ecol. Prog. Ser. 249, 183-197.

Wallace, W., Lopez, G., Levinton, J., 1998. Cadmium resistance in an oligochaete and its effect on cadmium trophic transfer to an omnivorous shrimp. Mar. Ecol. Prog. Ser. 172, 725-237.

Wang, X., Rainbow, P., 2005. Influence of metal exposure history on trace meta uptake and accumulation by marine invertebrates. Ecotoxicol. Environ. Saf. 61 $145-159$

Wu, J.-P., Chen, H.-C., 2005. Metallothionein induction and heavy metal accumulation in white shrimp Litopenaeus vannamei exposed to cadmium and zinc. Comp. Biochem. Physiol. C Pharmacol. Toxicol. Endocrinol. 140, 383-394.

Xie, L., Klerks, P. 2004. Fitness cost of resistance to cadmium in the least killifish (Heterandria formosa). Environ. Toxicol. Chem. 23, 1499-1503.

Zar, J., 2010. Biostatistical Analysis, fifth ed. Prentice Hall, New Jersey, p. 944.

Zhang, L., Wang, W.-X., 2006. Significance of subcellular metal distribution in prey in influencing the trophic transfer of metals in a marine fish. Limnol. Oceanogr. 51, 2008-2017. 